\title{
A critical review of theoretical aspects of strategic planning and firm performance
}

\author{
Assoc. Prof. Dr. Sadudin Ibraimi \\ Faculty of Business and Economics South East European University, \\ Ilinden 335, 1200 Tetovo, North Macedonia
}

\begin{abstract}
In this paper we examine the reasons and justify the striking interest being taken by researchers and managers on strategic planning, but also the limits of those principles, some intrinsic others that can be overcome by an integration with tradition. A framework which attempts to relate the constituent elements that distinguish the two main strategic theories and shows that both must be considered for strategic planning and performance management is provided.
\end{abstract}

Keywords Planning, strategy, resources, competitive advantage

\section{Introduction}

The academic and managerial debate on strategic management appears to have reached a crucial point. There is an active reconsideration of strategic management in general, in the ambit of which the traditional model of industrial organization is criticized by the upholders of the theories that regard the resources and competencies of a firm as its principal source of competitive advantage (thus not the strategic conduct suited to the industry as, in contrast, the traditional theory maintains).

In this article we carry out an analysis of one of the most recent and controversial branches of research pertaining to corporate strategy: that known as the resource-based view, competence-based competition, or dynamic capabilities view. These approaches, though with some fine distinctions, show the same layout and solution principles to such an extent that one can talk tout court of a "competence theory".

Competence theory is actually the most concrete and plausible alternative to the dominant strategic model of industrial organization. This latter was introduced at a pioneering level by Bain (1968) and successively developed by Porter $(1980 ; 1985)$. However, competence theory, in spite of the number of contributions, still appears as a series of interventions on different problems, treated according to a common prospective rather than a true theoretic body.

The intention of the analysis is to present the new strategic dictates in a critical form, on one hand examining the reasons that confer validity on them and justify the striking interest taken by researchers and managers, and on the other their limits, some intrinsic others that can be overcome by further work and integration with former theories, in particular industrial organization (whose basic concepts are well known and so are not outlined).

Having verified that the need to integrate new and old theories seems to be greater than their apparent irreconcilability, a framework to integrate industrial organization and competence theory is proposed. Starting from two different conceptions of the relation between strategy and competitive advantage, where the two approaches converge, attempts have been made to relate the various elements that distinguish them (Hisrich and Ramadani, 2017).

Besides an in-depth confrontation of industrial organization and competence theory, the innovative contribution of this paper lies in the integrated framework presented and in its implications for management.

\section{Limits and criticisms of industrial organization}


Those in favour of competence theory list a series of limits of Porter's theory, also known as industrial organization because of the importance it gives to industries; the limits are linked to the way of understanding the corporate strategy and can be summarized as follows:

$\square$ the strategy concerns the competitive positioning of the firm within an industry of a given structure: this is ever less true, given the difficulty of defining the boundaries of industries and in addition their instability;

the strategy aims at existing industries: in this way many possibilities are neglected; and

the strategy is the result of an analytical process, while its execution is an organizational

process: the phases of formulation and implementation of the strategy cannot be separated or made

sequential, according to the Porterian scheme "structure-conduct-

performance" (Prahalad and Hamel,1994).

Having outlined the limits of a general nature, the strictures made upon the industrial organization model which consequently lead to the affirmation of competence theory can be traced to the following specific points:

$\square$ The profitability of the firm determined by the industry to which it belongs (according to the sequence "structure-conduct-performance"). Rumelt (1991), in a well-known study, points out that the different profitability of firms depends on the performances of the single business units of a corporation, that is, on units operating in specific areas of business in an industry, rather than on the whole industry to which the firm itself belongs. The different profitability of firms must then be sought, firstly, not within the contextual factors such as position on the market, though they have a certain influence, but in what Nelson (1991) calls "discretional factors", that is a decisional process that enjoys a certain margin of autonomy ("business choices"): if factors exist that can be managed with a certain degree of freedom, it is inevitable that the firms obtain different results, though facing exactly the same competitive environment.

$\square$ The existence de facto of only two strategic options - cost-leadership and differentiation. Porter considers these options as alternatives, because they are founded on incompatible performances such as cost and quality.

The sustainability of the competitive advantage determined by five forces (competitors, the threat of new entrants, the threat of substitute products, bargaining power of suppliers, bargaining power of buyers). The most evident aspect of modification due to the impact of these forces regards the relations between firms and suppliers and customers. In recent years we have seen ties of collaboration and partnership developed with the suppliers, while relations with the customers have evolved from one of force to one of customer satisfaction.

$\square$ Besides, the entry barriers into an industry are often of minor importance in respect to the distinctive and difficult-to-copy characteristics of some firms: these peculiarities, in fact, act as deterrents to competitors.

$\square$ The relationship between strategy and technology. Porter seems to have both a static (he considers the actual strategy and technology) and an instrumental (technology as a means of obtaining a better position on the costs front or on that of differentiation) vision of technology. Reflections on the other two possibilities are missing, that is, consideration of the relationship between present strategy and future technology (often the current decisions on strategy influence the process of "technology accumulation") and between future strategy and present technology (the current technology characterizes the future strategy in terms of product and process innovations) (Itami and Numagami, 1992).

\section{Resource-based view}

The first researcher to propose a resource-based view was Edith Penrose (1959), even though her analysis of the resources was aimed at understanding the output of the firm rather than the definition of its behaviour. Only recently has interest in this approach arisen, mostly in a critical key and as an alternative to the industrial organization model, so within the ambit of strategic studies.

The seminal study on the theme was that of Wernerfelt (1984), though in some ways it still remains linked to the Porterian model. In fact, for Wernerfelt, "resources and products are two sides of the same coin", where the resources are understood as "the assets, tangible or not, which are semi-permanently linked to the firm". In practice, industrial organization would take care of maximizing profits, consigning the resources; resource-based view would, instead, concentrate on minimizing the cost of resources, given a certain level of profit. Wernerfelt then applied Porter's five competitive forces model to the resources, in particular he points out the existence of "resource position barriers", with a role similar to that of the entry barriers in an industry. 
Successive works decisively move away from the Porterian theory and make determinant contributions to the definition of resource-based view.

Grant (1991) first of all distinguishes between resources and competencies:

The resources are the input of the productive process, the basic unit of the analysis, which need accumulation and co-ordination. According to Grant, six categories of resources exist: financial; physical (plant capacity, availability of raw materials, etc.); human; technological (number and importance of patents, etc.); the reputation (recognition of the brand, customer fidelity, etc); and organizational (values, management styles, etc).

$\square$ The competencies [1] are placed at a higher level of the aggregation, and identify the capacity of a group of resources, if properly managed, to carry out an activity or reach a

target. The competencies explain how two firms, though with similar objectives and exactly the same resources, can achieve different performances, or vice versa, how two firms can obtain similar performances even if with different resources [2].

The conceptual distinction between resources and competencies is a typical connotation of resource-based view (Hisrich and Ramadani, 2018). Amit and Schoemaker (1993) refer to the resources as a group of possessed or controlled factors available to the firm, that can be transferred or acquired from outside, while the competencies represent the capacity to spread resources by means of organizational processes so as to obtain the desired results (they are the fruit, in contrast to the resources, of information developed, exchanged and spread among the personnel of the firm). Aaker (1989) distinguishes between "assets" and "skills": the former are linked to the possession, the latter to the doing. Dierickx and Cool (1989), in contrast, distinguish between "stock" and "flow": the stock accumulates over time thanks to the flow, which is easily modified unlike the former.

Grant (1991) thus asserts that firm's resources and competencies, on one hand provide the basic direction for a firm's strategy, and on the other are the primary source of profit for the firm.

Consequently, the strategic planning should be divided into the following phases:

(1)identify and classify the firm's resources, appraise strengths and weaknesses relative to competitors, identify opportunities for better utilization of resources;

(2) identify the firm's competencies, and the resources inputs of each competence;

(3) appraise the rent-generating potential of resources and competencies;

(4) select a strategy which best exploits the firm's resources and competencies relative to external opportunities; and

(5) identify resource gaps which need to be filled (invest in replenishing, augmenting and upgrading the firm's resources).

One of the subjects best treated by resource-based view regards the "sustainability of the competitive advantage", understood by Hall (1993) as "the "capability differential" maintained for a significantly long period".

Barney (1991), in a work that has become fundamental, individuates in the "heterogeneity" and in the "imperfect mobility" of the resources the conditions necessary for a sustainable competitive advantage; consequently the resources must:

$\square$ be valuable, increasing efficiency and effectiveness;

$\square$ be rare, in other words utilized by only one or few firms;

$\square$ be imperfectly imitable (due to one or more of the following factors: unique historical conditions; causal ambiguity, when the link between controlled resources and competitive advantage is not understood or only partially or in a vague manner; complexity of internal relations and those with the customers and suppliers); and

$\square$ be imperfectly substitutable, that is, equivalent resources from a strategic point of view do not exist.

In short, it can be stated that the definite conquest of resource-based view is due to the link established between the firm's internal resources and a sustainable competitive advantage. The role of the firm's external environment is re-evaluated (together with its five forces) when determining its competitive advantage and profitability. At the same time the hypotheses regarding perfect homogeneity of the distribution of resources between firms operating in the same industry and of their perfect mobility fail: to determine an advantage, the resources must confer on the firm that possesses them traces of uniqueness and non-imitability, neither can they be easily transferred or substituted. 
If all the firms were equal in regard to the endowment of resources, there would be no profitability differences among them and all would earn the same amount. The amount earned may not be proportional to the quantity of resources possessed, quantities measured in monetary terms: there are "resources" - or more exactly "competencies" - that are the ability to manage the resources, and thus difficult to evaluate, but can make the difference.

Besides, the differences between firms exist because there is not transparency and certain mechanisms between possessed resources and performances obtained are not well known, indeed the links are multiple and difficult to form. That is, at least for a certain period of time, the advantages of some firms, in respect to others, are protected and the efforts made to rise above the average are repaid.

One of the most strategically important firm's resources is knowledge: the knowledge-based view of the firm (the firm is conceptualized as an institution for integrating knowledge) is an outgrowth of resourcebased view (Grant, 1996). Since the origin of all tangible resources lies outside the firm, it follows that competitive advantage is more likely to arise from the intangible firm-specific knowledge which enables it to add value to the incoming factors of production in a relatively unique manner (Spender, 1996).

Knowledge management perspective,which privileges the consideration of intellectual resources, could enrich the debate on resource-based view, linking together the concepts of competence, governance, and entrepreneurship (Foss and Mahnke, 2000), treated in the paragraph on comparative analysis of competence theory and industrial organization. At the same, a completion of analysis could derive from studies not only on but also in organizations, testing cultural basis and ethnographic variables (Rouse and Daellenbach, 1999).

\section{Competence-based competition}

The first to mention "distinctive competence" was Selznick (1957) - though understood more in the sense of a bond than a variable on which to act - and the concept was treated those same years by the "Austrian economic school".

However, the strategic approach based on the competency's competence-based competition is much more recent (Snow and Hrebiniak, 1980) and has been outlined with strategic valences by Prahalad and Hamel (1990) in a well-known article in the Harvard Business Review. They think of the "core competencies" of a firm as the factors that determine its success (Lenz (1980) calls them "strategic capabilities").

Competence-based competition enters the field of studies on resource-based view, to such an extent that some authors do not distinguish between them (e.g. Porter, 1991); however it assumes a connotation precisely because of the emphasis placed on the "behavioural" aspect of strategic planning, that is, on its deliberativeness, proactive stance and amplitude of vision (Hamel and Prahalad, 1994). In particular, while resource-based view individuates practically ex post the resources that determine a competitive advantage, competence-based competition tries to understand a priori which are these resources/competencies. In addition - as Montgomery (1995) observes competence-based competition follows a process orientation that resource-based view does not consider.

According to competence-based competition, a solid competitive advantage is based on the capacity to create, strengthen, and broaden the firm's core competencies to make new products that will be a success on the market. Prahalad and Hamel (1990) define "core competence" as "the collective learning in the organization, especially how to co-ordinate diverse production skills and integrate multiple streams of technology": they quote for example

- among others - Sony's capacity to miniaturize, Canon's optical technology, and Honda's engine design.

A "core product" is the "physical representation" of a core competence, as that which makes a core competence visible is not the final product but a product (or part or subset) that is at a level intermediate between the competencies and the finished products (also called "product platform" (Meyer and Utterback, 1993)). In Prahalad and Hamel's (1990) view, the diversified firm resembles a tree, where the core competencies are the roots which supply food,support and stability.

Core competencies to be such must:

permit potential access to a high number of markets;

be seen by the end customer as the principal source of value added to the product; and

be difficult to imitate by the competitors.

Competencies, in contrast to material goods, increase the more they are used and shared. The non-material resources in fact are characterized by: ability to settle through people ("organizational 
memory"), uniqueness, difficulty to acquire, difficulty to copy, multiplicity of uses, perishability if not used, and being incremental.

Competence-based competition could be compared to the capabilities-based competition of Stalk et al. (1992), which accentuates the aspects of closeness to the customer and extension of the capabilities/competencies along the entire value chain of the firm. The need to abandon functional management and proceed in a transversal manner is common to both ("the building blocks of corporate strategy are not products and markets but business processes"). Also, the importance given to the human factor (the capacities, in virtue of their transversal and collective nature, for the most part do not exist in a small number of people, but a large number of people each playing a small part), and the flexible dynamic character are recognized as the strategy to adequately face market instability (we have passed from a "war of position" to a "war of movement", and need to have "acuity" to foresee the future development of the markets). So firms need, according to the analogy made by Stalk et al. (1992), to be "capabilities predators", that is move rapidly from one business to another, copying capacities, developing them so as to assume the role of leader, and this is possible only thanks to flexible human resources and transversal management of the firm.

This is aligned with the thesis of Cockburn et al. (2000), for whom the origins of competitive advantage lie in the ability to identify and respond to environmental cues well in advance of observing performanceoriented pay-offs.

\section{Dynamic capabilities view}

Also following the dynamic aspect just faced by Stalk et al. (1992), much more consideration for the evolution of firm capabilities has appeared in recent works (including a special issue of Strategic Management Journal (Helfat, 2000)). One of the major themes deals with the question of how it is that, over time, some firms manage to become successful using their capabilities, while other firms do not. Furthermore, how does the nature of technology and markets affect the ability of firms to alter their capabilities over time in order to prosper? And under what conditions do successful firms in an industry end up with relatively different vs. somewhat similar capabilities?

The framework for dynamic capabilities is own to Teece et al. (1997), who theorize that competitive advantage of firms rests on distinctive processes (ways of coordinating and combining), shaped by the firm's (specific) asset positions, and the evolution path(s) it has adopted or inherited. They distinguish:

$\square$ models of strategy emphasizing the exploitation of market power (like the competitive forces of industrial organization or the game theory for studying the nature of competitive interaction between rival firms);

models of strategy emphasizing efficiency (like resource-based view, which is based, according to Teece et al. (1997), on scarce firm-specific resources); and

a dynamic capability approach.

In this latter case, the term "dynamic" refers to the capacity to renew competencies so as to achieve congruence with the changing business environment, given path dependencies and actual market positions. The term "capabilities" emphasizes the key role of strategic management in appropriately adapting, integrating, and reconfiguring internal and external organizational skills, resources, and competencies to match the requirements of a changing environment.

As a consequence, competitive advantage of firms seems to lie with their managerial and organizational processes (the way things are done in the firm, or its routines, or patterns of current practice and learning), shaped by their (specific) assets, market position, and paths done.

Eisenhardt and Martin (2000) recognize that dynamic capabilities are a set of specific and identifiable "processes" (such as product development, strategic decision making, alliancing, etc.), which have commonalities across firms in terms of key features (popularly termed "best practice"), in so violating the resource-based view assumption of heterogeneity across firms. So where does the potential for long-term competitive advantage lie? It lies, according to Eisenhardt and Martin (2000), in using dynamic capabilities sooner, more astutely, or more fortuitously than the competitors; therefore, long-term competitive advantage lies in the resource configurations that managers build using dynamic capabilities, not in the capabilities themselves.

Furthermore, Eisenhardt and Martin (2000) distinguish between moderately dynamic markets, in which dynamic capabilities are more homogeneous, fungible, equifinal, and substitutable than is usually assumed, 
and high-velocity markets, where these processes are highly experiential and fragile, with more unpredictable outcomes, and emphasis on selection (new knowledge created for new situations) rather than variation (embedded in cumulative existing knowledge). So, in both cases, orthodox resource-based view misses the reality.

Makadok (2001), rather distinguishing between moderately dynamic markets and high-velocity ones, evidences two different causal mechanisms about how firms create economic rents: a "resource-picking" mechanism (being more effective than rivals at selecting resources) and a "capability-building" mechanism (being more effective than rivals at deploying resources). These two rent-creation mechanisms are complementary in some circumstances but substitutes in others.

\section{Limits and criticisms of competence theory}

The limits and the criticisms of competence theory regard both the common bases of resource-based view, competence-based competition and dynamic capabilities view, and the organizational-managerial aspects, thus concerning mainly competence-based competition (dynamic capabilities view, also being newer, is actually far less criticized). Regarding the common foundations of competence theory, the criticism centres on:

The exclusive interest for a single firm, taken out of the industrial context.Some authors (Porter, 1991; Amit and Schoemaker, 1993) have tried to overcome this limit, considering competence theory and industrial organization together (see the successive paragraph).

$\square$ The lack of a theoretical model which clearly defines the links between resources and competencies on one side, and sustainable competitive advantage on the other.

According to Doz (1996), the lack of "a solid empirical base and of a micro-theoretic foundation" makes it difficult to establish and discriminate the effects of single resources/competencies on the performances of the firm. This results in the serious problem not only of the a priori, but also of an a posteriori analysis, aimed at individuating the causal connection between resources/competencies possessed and the performances obtained.

$\square$ The not well clarified relationship between deliberateness and chance.In contrast to what competence theory affirms, it cannot be denied that several innovations and important competencies were generated without having been foreseen and even less apparently in a completely fortuitous manner"stochastic"(Wernerfelt 1995; Ramadani and Gerguri, 2011; Gerguri et al., 2013; Ramadani et al., 2013).

$\square$ The application of the theory exclusively to large, advanced, diversified firms, which compete on a world scale, typical of business school firms).

In regard to the criticisms made more specifically of competence-based competition, there are:

$\square$ The doubts about the real value of the organizational competencies. For some authors the importance attributed by competence-based competition to the organizational competencies is excessive: no strategic analysis can accurately foretell the future consented by the present capabilities. Besides, as the improvement is continuous and unstoppable, there cannot exist consolidated competencies which will generate competitive advantage in the long term (Collis and Montgomery, 1995).

The rigidities that the competencies can cause in an organization ("organizational inertia" (Rumelt, 1995)). There is a "paradox between 'core capabilities' and 'core rigidities' in the development of a new product" (Leonard-Barton, 1992). On one hand the competencies possessed are important, particularly the technical ones, to develop a new product in a short time and at a reasonable cost. On the other, especially if the projects are extremely innovative, it is necessary to change the values and organizational culture which could be hindered by the present competencies (Ghemawat, 1991).

$\square$ The dilemmas that the management must face in the handling of the competencies (for example, an explicit diffusion of the competencies versus a sufficiently free and autonomous process of learning, a difficult integration of very specific competencies versus an easier integration of less specific competencies, making use of the existing

competencies versus a search for new competencies, etc.(Doz, 1996)).

Montgomery (1995), besides criticisms and limits, lists some fundamental characteristics of competence theory that should be "re-evaluated"; these include: 
$\square$ the optimism and emphasis placed on the capacity of the resources to give a competitive advantage;

the excessive attention given to a restricted number of resources, the so-called

"strategic" ones, while resources are neglected which, though not generating competitive advantages, are fundamental to the positioning on the market and survival

("that is, the consideration of a middle way between triumph and death is missing");

$\square$ the scarce consideration of how the resources can lose value, seeing that this can happen in a much

shorter time than the reverse process; and

$\square$ the lack of consideration of the negative impact (a bad reputation, running into debt, etc.) that certain

"resources" can cause.

There also more radical criticisms at competence theory. D'Aveni (1994) discusses the sustainability of competitive advantage; in particular, it argues that the successful key for success is the continuous distruption and reconstruction of competitive advantage ("hypercompetion"), through always new factors, therefore not exploiting and consolidating an asset of resources and competencies. The inimitability of resources is substituted by an unpredictable competitive conduct.

Lengnick-Hall and Wolff (1999) view three "approaches to strategy": a capability logic (our competence theory ), a guerrilla logic (similar to the preceding hyper competition), and a "complexity logic" ("where the strategic success is a function of a firm's talent for thriving in dynamic nonlinear or chaotic systems, that rely on network feedback and emergent relationships . . . a blend of competition and cooperation . . . a dynamic tension embedded between various actors and processes, as well as between a firm and its context").(See also Senge (1990) on leadership, and the "the science of management complexity" by Stacey (1996).)

Priem and Butler (2001), in a famous recent article, strongly criticize competence theory, underlining an "elemental fallacy" of resource-based view in particular. In fact, the resource-based view value definitions clearly show that is the market environment that determines the degree of value held by each firm resource in resource-based view; thus, resource value is determined from a source exogenous to resource-based view, which instead makes an implicit assumption of homogeneous and immobile product markets (while product and customer factors vary so that resource value should vary too).

Barney (2001) replied to Priem and Butler, introducing a sort of parametrization in respect to the environment or market structure; this "parametrization" regards: value, rarity, imitability of the resources. $\mathrm{He}$ also tried to overcome the tautology critique (only valuable resources can be sources of competitive advantage, but this is the feature of valuable resources), inviting not to confuse cause and effect: "if the relative value of a firm's competitive actions are effects, the resource-based logic indicates that attributes of firm resources - their value, rarity, imitability, and substitutability - are the causes".

In the same work, Barney (2001) widens the resource-based view spectrum analysis, considering the "strategic alternatives": "to the extent that developing strategic alternatives a firm can use to exploit the resources it controls is a creative and entrepreneurial process", a kind of capability itself in the rent appropriation process by the stakeholders ("first, the ability to implement strategies is, itself,a resource . . second, implementation depends on resources").

\section{Comparative analysis of competence theory and industrial organization}

As was seen in the paragraphs above, industrial organization and competence theory have different features, to such an extent that at times they seem irreconcilable and any attempt at their integration difficult. The objects to be analyzed appear too different, the interpretation of the causes at the source of the firm's profitability, the suggested way of managing and selecting strategic options; the only point in common seems to be the consideration of the competitive advantage in terms of value offered to the customer, though again the causes for the sustainability of this advantage are different(Table I).

The merit of competence theory, and its growing esteem or re-evaluation, are due it having shifted the attention of managers and researchers to the resources, the firm's competencies and strengthened the branch of studies called "inside-out" (which analyzes the source of the competitive advantage starting from inside the firm), in contrast to the dominant school of thought defined as "outside-in" (which analyzes the source of the competitive advantage starting from outside the firm, that is from the industry), and can be traced to Porter's(1980,1985)competitive model. 


\begin{tabular}{|c|c|c|}
\hline & Industrial organization & Competence theory \\
\hline Object of analysis & The industry & The firm \\
\hline $\begin{array}{l}\text { Firm } \\
\text { characteristics }\end{array}$ & Typical of the industry & Unique \\
\hline Source of rent & The industry & Resources and competencies \\
\hline Industry & $\begin{array}{l}\text { Fixed, the strategy } \\
\text { conform to it }\end{array}$ & In evolution and difficult to define \\
\hline Management & Portfolio of businesses & Portfolio of competencies \\
\hline Strategical options & $\begin{array}{l}\text { Cost-leadership } \\
\text { differentiation }\end{array}$ & $\begin{array}{l}\text { Depend on competencies and } \\
\text { core products }\end{array}$ \\
\hline Resources & Allocated to the business units & Transversal to the business units \\
\hline $\begin{array}{l}\text { Competitive } \\
\text { advantage }\end{array}$ & $\begin{array}{l}\text { Based on the value for the } \\
\text { customer }\end{array}$ & $\begin{array}{l}\text { Based on the value for the } \\
\text { customer }\end{array}$ \\
\hline $\begin{array}{l}\text { Sustainability of } \\
\text { the } \\
\text { competitive } \\
\text { advantage }\end{array}$ & $\begin{array}{l}\text { Depends on five forces (current } \\
\text { and potential competitors, } \\
\text { substitute products, buyers } \\
\text { and suppliers) }\end{array}$ & $\begin{array}{l}\text { Depends on the heterogeneity, } \\
\text { the imperfect mobility, imitability } \\
\text { sland substitutability of the } \\
\text { resources }\end{array}$ \\
\hline
\end{tabular}

Table I. Comparative analysis of competence theory and industrial organization

This revived attention paid to the single firm poses, however, the problem of the relations with the industry analysis, risks underestimating the influence of the latter, and in short challenges the researchers to construct a theory which considers jointly, and in a balanced manner, the firms' particular characteristics and those of the industry in which it operates.

In reality the link between "inside view" (the firm) and "outside view" (the market) has already been made by Andrews (1971). He defined the strategy as the combination between what a firm can do (strong and weak points) in the ambit of all that it could do (opportunities and threats) - a model known as SWOT, from the initials of strengths, weaknesses, opportunities, and threats.

"The resource-based view can be seen as an excellent starting point for analysis of the relative strengths and weaknesses of firms, while a strategic positioning approach (i.e. industrial organization) is probably the cornerstone of any opportunities and threats analysis" (Rugman and Verbeke, 2002).

In essence, it could be said that the two main schools of strategic management (on one side that of Chandler (1962) and Andrews (1971), or the Harvardian school of business policy, considers the strategy in the broad sense, as the firm's targets and means available, and on the other side that of Ansoff (1965) and Hofer and Schendel (1978), considers the strategy in the narrow sense, as only the targets pursued), the Harvardian one, though later projected to the outside in the first contributions made by Porter $(1980,1985)$, was not in reality very far from an attempt to integrate resource-based view and industrial organization, as recognized recently by Porter (1996).

Wernerfelt (1984), who can be considered to have initiated the line of research on competence theory, did not think of it as an alternative to the industrial organization theory but,according to him, the conditions that give value to the resources are not unlike, mutatis mutandis, those which mould the structure of an industry according to the industrial organization theory: resources (meant as strategic) that are more or less difficult to acquire,on the market correspond to a greater or lesser bargaining power of the suppliers of materials, the substitutability of the aforementioned resources is analogous to the threat of substitute products, while the impossibility of copying the resources of a firm are the counterpart, in an industry, of the entry barriers and mobility. 
Successive contributions have moved competence theory ever further from industrial organization. As a result there is an increasing number of papers which aim at overcoming that distance and critically reconsider both approaches, integrating them as far as possible into a joint vision. The most important of these are by Porter (1991),Schoemaker (1992), Amit and Schoemaker (1993), Mahoney and Pandian (1992),

Foss and Eriksen (1995), and those related in some ways to the organizational economics, all of which will be summarized in the following sub-paragraphs;instead, in the next paragraph, the authors advance their own proposal for integration.

But before examining contributions aimed at jointly considering industrial organization and competence theory,let us also mention two parallel research streams.

The first one is that opened by Eisenhardt and Sull (2001), who define a third way for strategy, besides "position" (i.e. industrial organization, based on establishing position in attractive markets with the question: "Where should we be?") and "resources" (i.e. TC, based on establishing a vision with resource leverage with the question: "What should we be?"). The new strategic alternative is named "simply rules", because it is based on key processes and unique simply rules, aimed at pursue opportunities in rapidly changing and ambiguous markets ("When the business landscape was simple,companies could afford to have complex strategies; but now that business is so complex, they need to simplify"). The question is now: "How should we proceed?". We think the proposal has merits, but more for stimulating the strategic debate in general than for really introducing a new strategic theory.

The second parallel stream regards the relationship between strategic management (the ambit of industrial organization and TC) and entrepreneurship. Entrepreneurship comes first, because is about firm creation; strategic management is about how advantage is established and maintained from what is created. Several authors (e.g. Hitt et al., 2001 (editors of the relative special issue of Strategic Management Journal) underline the necessity of a much more integration between the two ambits: "one of the domains in which the integration between entrepreneurship and strategic management occurs naturally is that of resources and organizational learning". In fact, at the origin of the firm/wealth creation is an entrepreneurial mindset, a capability for vision under highly uncertain conditions, which is a unique and inimitable resource. This stream is very recent and - though it does not integrate industrial organization and competence theory, it could help in clarifying some particular intangible resources of the firms.

\section{Porter's view}

Porter, who with reason can be considered the principal advocate of the industrial organization theory, could not remain silent in front of the criticisms and new proposals of the competence theory supporters.

According to Porter (1991), competence theory proposes to bring, to the strategic reflection, new answers to the "longitudinal problem", which consist of the individualization of the conditions that permit a firm to reach and hold on to a favourable competitive position over time. This problem, however, cannot be separated from the "cross-sectional problem", aimed at understanding the causes at the base of the firm's superior performance at a precise instance in time.

Porter (and this is also the opinion of Collis and Montgomery, 1995) believes that the industry or business must remain the principal unit of analysis, as the possession of determinate resources or competencies should be, in any case, compared with those of the competitors: it follows that the firm profitability depends both on the attractiveness of the industry in which the firm competes and on its relative position in that industry. Then, if "the essence of strategy is choosing to perform activities differently than rivals do", the core competencies enable the choice of diversity to be followed (Porter, 1996).

Porter (1991) presents a framework (Figure1)in which the activities are the source of competitive advantage. Performing an activity requires tangible assets (physical and financial) as well as intangible ones (embodied in human resources and technology). While the tangible assets normally depreciate, the intangible ones can cumulate over time. The assets originate from external acquisitions or the practice of the activities themselves, and thus have, as a background, the managerial choices made over time, starting from certain initial conditions of the firm.

The reason why firms are able to carry out activities at a lower cost or in such a way as to create a greater value for the customer lies in that which Porter calls "drivers", and which - as we see it - are nothing more than those particular assets that permit activities which determine competitive advantages to be carried out.Thus, while the cross-sectional problem can be better understood by analysis of the industry, 
competence theory (which then is not given as an alternative but as a complement) can answer some questions linked to the passing of time, in other words to the longitudinal problem.

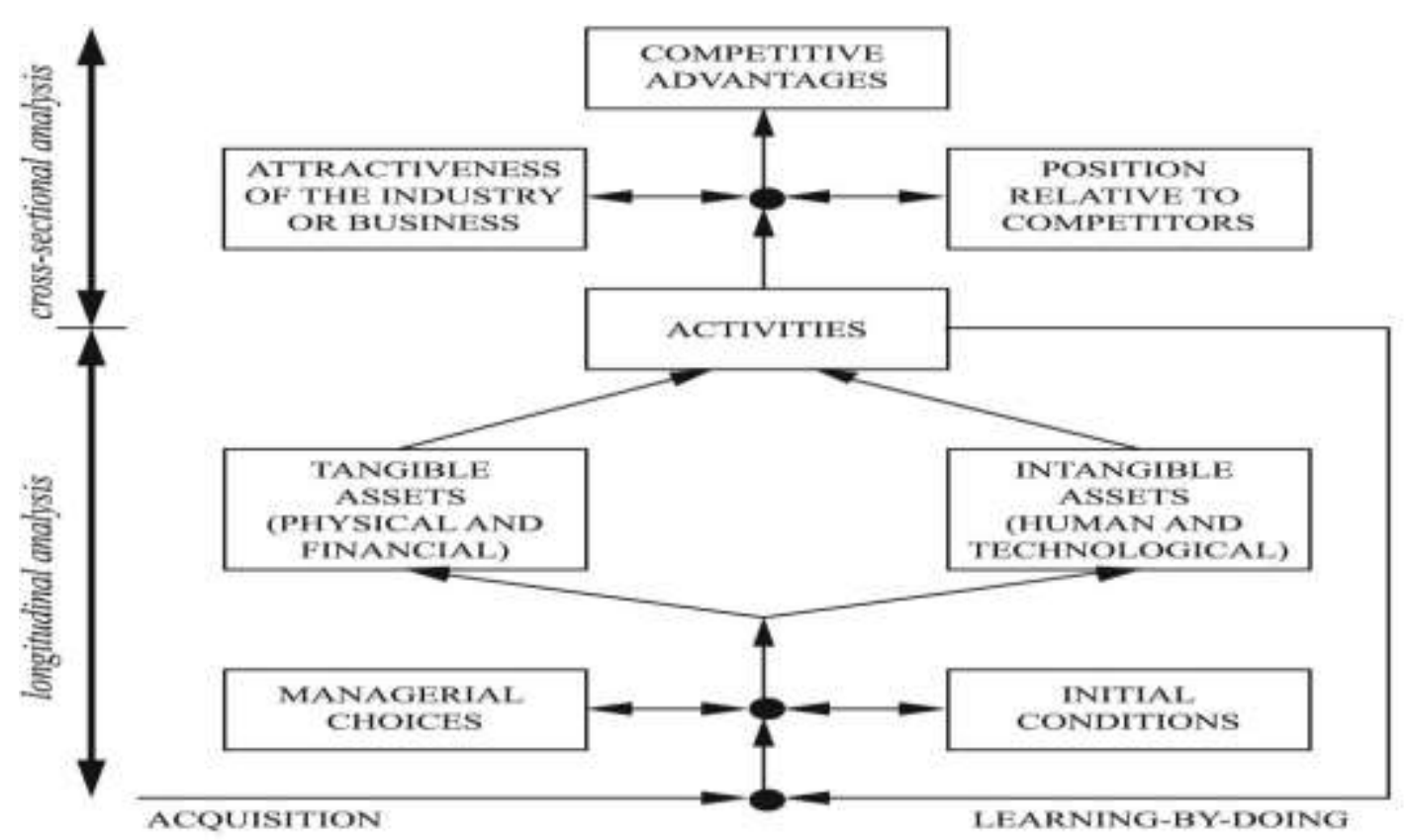

Figure:1PThe source of competitive advantage to Porter

\section{Schoemaker's and Amit-Schoemaker's view}

Schoemaker (1992) considers the so-called "strategic vision" to be the unifying characteristic of the two approaches (industrial organization and competence theory). It is none other than the answer to the most important questions that the firm managers must pose: how to keep a competitive advantage, which new products and markets to aim at, etc. This is the global vision of the firm, where both specific resources and agent forces at the industry level have a place; this vision is realized through four phases:

(1) generate broad scenarios of possible futures;

(2) conduct a competitive analysis of the industry and its strategic segments;

(3) analyze the company's and the competition's core capabilities; and

(4) identify the strategic options.

The choice of strategic options thus passes through the analysis of the competencies, and not only according to industrial organization - through the industry analysis.

Together with Amit, Schoemaker maintains that the profitability of a firm derives from the amount of overlapping and convergence between "strategic assets" and "strategic industry factors"(Amit and Schoemaker, 1993) (see Fig. 2):

$\square$ The strategic assets (technical abilities, brand management, control of distribution channels, etc.) coincide with the resources/competencies according to competence theory. In other words, they are specific of a firm, difficult to imitate or transfer, they confer competitive advantage, and derive from the incomplete rationality of the managers and their predisposition to risk (otherwise the firms, apart from their initial conditions, would operate in a regime of stability, copying the best firms, and thus there would not be any substantial difference in profit between the firms).

The strategic industry factors are resources and competencies at the industry/market level. Thus, they more or less characterize all the firms that possess them and explain their success in respect to other industries/markets.

$\square$ Thus, a firm could reach a higher than average income if it belonged to a profit-bearing industry, marked by specific "strategic factors", but anyway the income would be different from that of all the other firms of the industry because of the unique specificity of that company, that is because of its "strategic assets". 


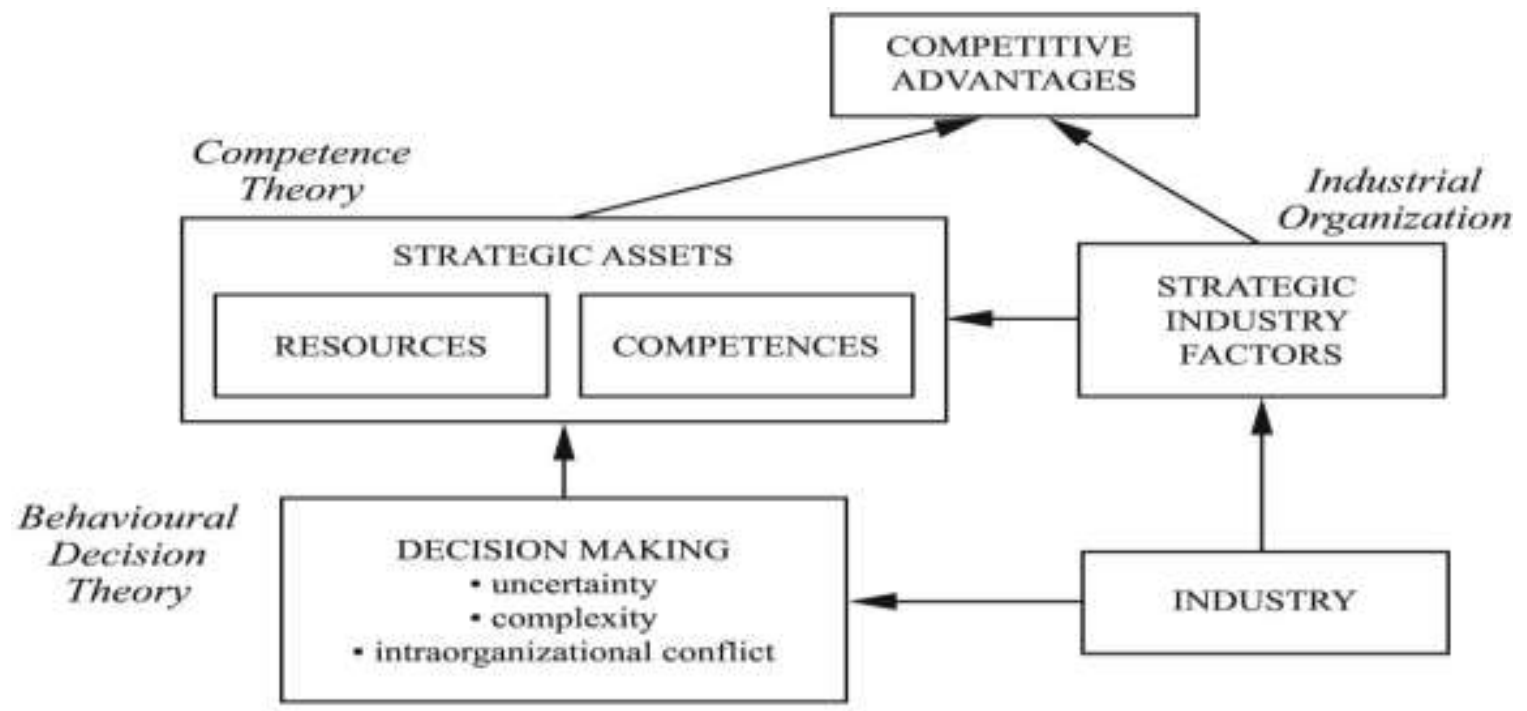

Source: Amit and Schocmaker (1993)

Figure 2. The source of competitive advantage to Amit and Schoemearker

Amit and Schoemaker (1993) besides competence theory and industrial organization, also consider the behavioural decision theory (Cyert and March, 1963), according to which when managers determine a strategy problems intervene that are linked to (Figure 2):

$\square$ the uncertainty (of the economic, social and technological environment, and the behaviour of the competitors and customers);

the complexity (numerous interrelated variables have to be evaluate);

the intraorganizational conflict (between who decides and who "suffers" the decisions).

Without uncertainty, complexity and conflict, the process of strategic planning would be perfectly rational and its results probably optimal, but also duplicable without particular difficulty. In other words, the behavioural decision theory and competence theory would explain why the equilibrium within an industry or of a market segment have finite lives, that is, it would give industrial organization a dynamic-evolutive perspective.

\section{Mahoney and Pandian's confrontation view based on the isolating mechanisms}

Among the other attempts made to integrate competence theory and industrial organization, those of Mahoney and Pandian (1992), Foss and Eriksen (1995), and Schroeder et al. (2002) are worth noting.

The unifying concept between the two approaches is - according to Mahoney and Pandian (1992) - that of the "isolating mechanisms", defined at the level of each single firm by the supporters of competence theory (barriers to imitation), but corresponding to entry and mobility barriers respectively at the level of industry and of "strategic group" (that is in the ambit of industrial organization(Porter,1980)

The key problem in the individualization of the rent determinants thus shift towards the analysis of the isolating mechanisms, operating at both the "micro" (the corporation) and the "macro" (the industry or the strategic group) levels, and their combinations.

At the "micro" level, the barriers to imitation are met (typical of competence theory), which regard the specificity of the resources possessed by the firm, the complexity of their individualization and interpretation, the aspect of tacit knowledge that often distinguishes them, the close dependence on the firm's history ("path dependency" (Dosi et al., 1992) and culture.

At the "macro" level, entry and mobility barriers are met. Typical entry barriers to an industry, and in a wider sense also mobility within an industry, are: the economies of scale, the capital requirements, possible costs of conversion, access to distribution channels, the product differentiation (brand image and customer fidelity), the government policies in terms of laws and regulations, the learning curves, patents and trademarks, favourable geographic position and privileged access to the raw materials (Porter, 1980). 


\section{Foss and Eriksen's "industry capabilities"}

Foss and Eriksen (1995) underline the importance of extending the investigation beyond the boundaries of the firm, a fact neglected by the upholders of resource-based view and barely considered by those of competence-based competition in the ambit of the strategic alliances and in general the various forms of collaboration between firms (Lei and Slocum, 1992).

They introduce the concept of "industry capabilities", competencies of firms adhering to an industry or of a strategic group, so they do not belong to an individual but are a shared property, even in the absence of explicit co-ordination, and as such will generate income (one thinks, for example, of the industrial districts). The "industry capabilities", as the firm's competencies, are the result of an irreversible process of accumulation, produced thanks to the integration of resources and competencies. The "industry capabilities" are thus analogous to the "strategic industry factors" of Amit and Schoemaker (1993).

In particular Foss and Eriksen (1995) assert that every firm must choose a strategic position in a Euclidean space consisting of resources and competencies, both individual (that is, specific to the firm) and collective (that is, typical of groups of firms); in this positioning, the managers must evaluate the distance they intend to keep between the firm and its competitors, in other words follow a heterogeneous or homogenous assetaccumulation strategy.

Heterogeneity is advisable from the competence theory viewpoint, as the acquisition and development of homogeneous competencies would preclude the search for a higher than average income. On the other hand, following a strategy oriented towards homogeneity has advantages linked to the possibility of learning from the competitors and preparing faster the resources necessary for success in an industry.

Competence theory and industrial organization thus become strategic theories in the ambit of which prevail, respectively, a strategy of heterogeneity and a strategy of homogeneity (in respect to the other firms in an industry).

Starting from similar positions, Levinthal (1995) points out the heterogeneity resulting from the present competition, in particular, the differences existing between the firms are increased by interaction with the market. Two types of mechanisms are involved:

(1) "self-reinforcing"; and

(2) "co-evolution".

The former mechanism refers to the fact that in many cases favourable market positions are consolidated in a measure more than proportional to the investments made. The second mechanism finds confirmation in the capacity and longsightedness of some managers, who, besides deciding the fate of their own firms, can also influence the evolution of the industry to which they belong.

Internal learning derives from employees' cross training, multiple tasks and suggestion systems; external learning instead comes from long-term relationships and close communication with suppliers, together with an active involvement and feedback from the customers.

\section{Firm's external linkages for supporting internal capabilities development}

The theme of external networks forcing the internal capabilities development has becoming more and more frequent in literature. For instance, Lee et al. (2001) distinguish between the cooperative "bilateral" contribution of partnership-based linkages (measured by strategic alliances with other enterprises, collaborations with universities and research institutes, and partecipation in venture associations) and those "unilateral" from sponsorship-based linkages (consisted of financial and nonfinancial support from commercial banks, public institutions and government).

The inter firm cooperation as a source of competitive advantage further enriches the confrontation debate between an (internal) competence theory view and an (external) industrial organization one. It is very interesting the relationship with organizational economics (Williamson, 1975), which is based on "transactions cost": interfirm arrangements observed in contemporary economies represent alternative ways of organizing and can permit superior performance in respect to simple market transactions.

Nevertheless, firms in need of "certain resources" (capabilities) will have to use interfirm cooperation even when cooperation would be not justified from a traditional OE perspective (according to organizational economics, cooperation is advisable only if it minimizes the cost of governing organizational activities) (Combs and Ketchen, 1999). This suggests the existence of resources/competencies not fully measurable in monetary terms, but that could make the difference. 
The same father of organizational economics, Williamson (1999), in his recent paper, sees "the relation between competence and governance (i.e. organizational economics) as both rival and complementary more the latter than the former, since some of the differences turn out to be more apparent than real . . . governance is more microanalytic (the transaction is the basic unit of analysis) and adopts an economizing approach, whereas competence is more

composite (the routine is the unit of analysis?) and is more concerned with processes (especially learning)".

\section{A proposal for the integration of competence theory and industrial organization}

The authors propose a framework for the integration of competence theory and industrial organization (Figure 3). Starting from the two different concepts of the relations between strategy and competitive advantage, where the two approaches converge, they try to relate the various elements that distinguish the two theories, and to show the need to consider both to make a complete analysis. The two theories are presented separating the constituent elements and articulating them according to a sequential scheme of analysis. On the left Figure 3 shows the scheme characterising industrial organization (sequence 1-2-3-4), on the right that characterising competence theory (sequence A-B-C-D).

The scheme of the strategic analysis according to industrial organization resumes Porter's well-known sequence "structure-conduct-performance": the industry structure (1), that is, the competitive environment in which the firm operates, positioning itself within the market and with regard to the competitors, suggests and describes the firm's conduct or strategic decisions

(2). These are realized in the selection of competitive priorities (3.1) (in other words, in the identification of the key success factors of the industry) and in the fulfilment of the intervention choices (3.2) most in keeping with the attainment of these competitive priorities. Even though representing both the competitive priorities and the intervention choices, the contents of a strategy are defined according to a sequence that first examines the definition of the competitive priorities and then the definition of the intervention choices. Then the conduct determines the firm's performances (4) and thus the competitive advantage.

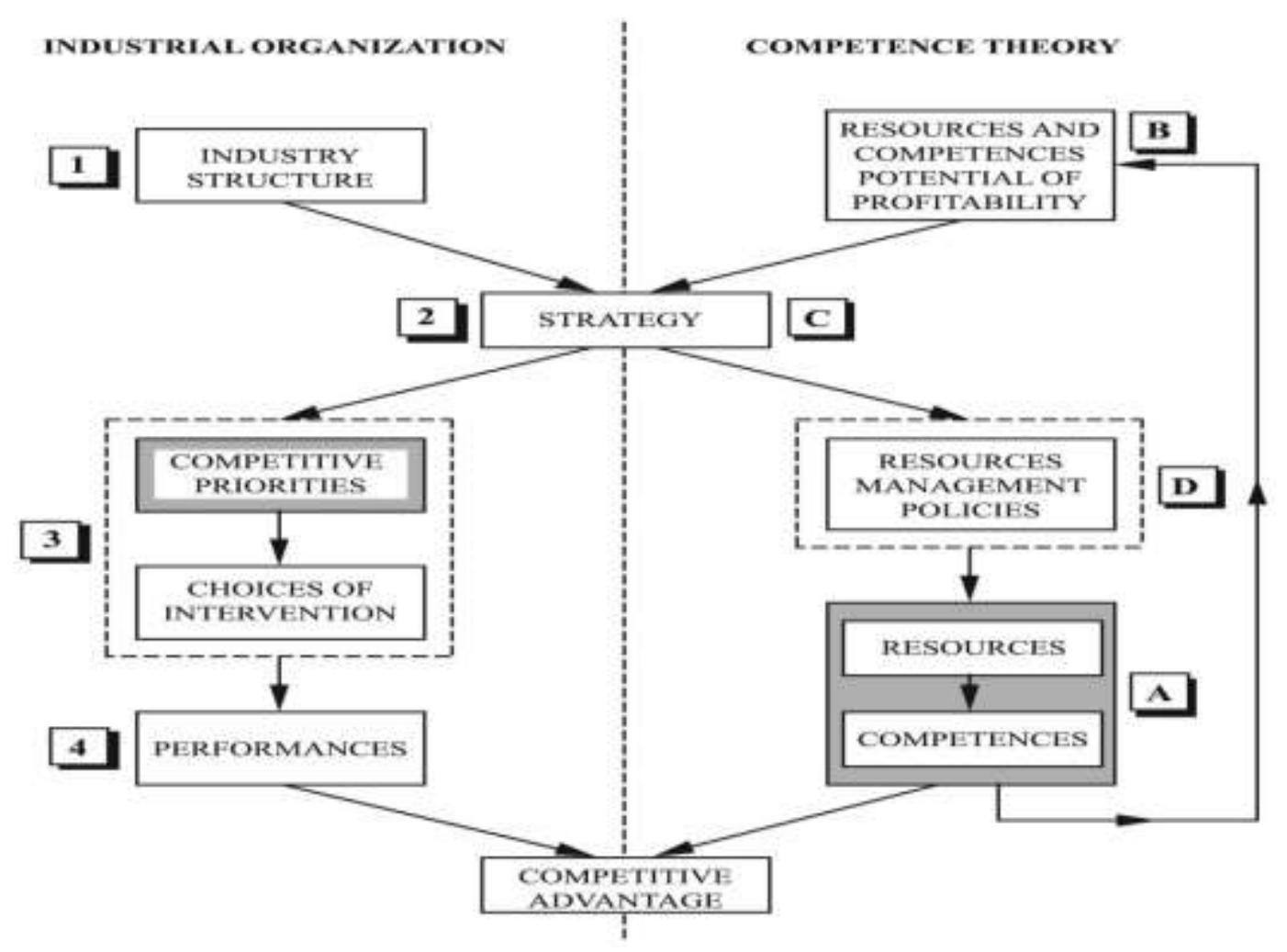

Figure 1. Proposal for the integration of competence theory and industrial organization by the joint analysis of competitive priorities and resources

The scheme of the strategic analysis according to competence theory (and Grant (1991) in particular[4]) can, on the other hand, be represented by the sequence: (A) analysis of the resources/competencies possessed (with the noted distinction between resources and competencies); (B) evaluation of their profitability 
potentials; (C) consequent definition of a strategy fitted to exploiting, valorizing and consolidating them; (D) realization of that strategy using appropriate policies to manage the resources[5].

Hence the resources, from one point of view constitute the source of the competitive advantage, from the other they define the strategic direction of the firm, according to the virtual circle typical of the "learning organization" and recognizable in Figure 3 on the right.

Therefore, according to competence theory, the strategy cannot be translated as the definition of competitive priorities and choices of intervention (as in industrial organization), but as the definition of the policies which are best suited to the management of the resources. The two different ways of seeing the strategy are evident in Figure 3 in the dotted squares.

The single elements of the proposed model are always related to the environment: the value of the performances or of the resources/competencies is not absolute but depends on that of the competitors, the competitive priorities change according to the industry, the possibilities of intervention depend on the technology available and on the social-economic variables, the competitive advantage may not be sustainable in relation to changed environmental conditions, etc.

Having defined and articulated the constituent elements of the two theories, let us look which could be the possible points of contact.

Besides the strategy and the common objective of the competitive advantage, the link between the branch on the left industrial organization and that on the right competence theory of Figure 3 is given by the comparison between competitive priorities on one side and the resources/competencies on the other (both shaded to highlight this link): the industrial organization model requires verification of the practicability of the competitive priorities considering the resources and competencies possessed. Likewise, the competence theory model which, for the acquisition, concentrating and conserving of the resources, needs confrontation with the key success factors present in the industrial organization model.

In other words, the postulation of industrial organization, which describes the derivation of the competitive priorities from the industry analysis is insufficient and needs the confrontation with the possessed resources/competencies, which can confirm certain priorities or re-direct towards others, having analyzed the potential profitability of the resources/competencies available. Similarly, the resources/competencies typical of a firm are of value not only if compared with the outside (industry or market) but also in relation to the competitive priorities selected by the firm.

In conclusion, both the competitive priorities and the resources/competencies are analyzed in two ways: in respect to the outside (the environment in terms of industry/market) and between each other.

In the link between competitive priorities (performances on which to focus) and resources/competencies may lie the key to surmounting much discussion on the theme of competencies and their strategic value, even though this relationship remains anything but clear, and scantily supported by empirical studies.

\section{Implications for the decisional processes of management}

The model proposed in Figure 3, shows the two strategies, in terms of competitive priority/intervention choices and in terms of management policies regarding resources/competencies. It could be a valid help for managers during their decisional processes. Whether these latter concern the re-engineering of the portfolio of activities, or society acquisition/stripping, it is essential to have a twofold viewpoint: "external" (suggested by industrial organization) and "internal" (suggested by competence theory) views in sight.

The two must, however, complement and enrich each other and this can take place through the confrontation between competitive priorities and resources/competencies. Consequently, in an operative logic, each manager must:

analyze the suitability of the competitive priorities selected by his firm (and of the consequent choices/intervention levers) for the environment in which the firm operates;

analyze the value of the resources/competencies possessed by the firm, not only in regard to itself but also to the environment (competitors and industries);

$\square$ verify if these competitive priorities are adequately supported by the resources/competencies possessed, and if necessary improve or manage them in a different way, or even modify the competitive priority; and

verify the true values of these resources/competencies, which do not depend only on the comparison with the competitors, but also on their suitability for the competitive 
priorities selected.

Figure 4, which sets off the horizontal links present in Figure 3, shows the above-mentioned four moments. They are all equally important and worthy of consideration in the decisional process at the managerial level. Then we briefly report some cases illustrating - in synthesis - firms that, in the ambit of their strategic planning, have emphasized certain of the preceding points.

In Benetton - the world leader in distinctive casual apparel - the initial managerial competencies of the upstream and downstream networks determine and support the choice and maintenance of the competitive priorities. In fact the firm's competitive priorities (a "global" image highly characterized by "the colours") are not only the result of strategic decisions linked to sector analysis, but, and above all, the exploitation and consolidation of resources and competencies accumulated over the years. These include the avant-garde supplying logics (both through the automated warehouses in Castrette and the "world wide" telematic connections) on one side, control of the raw material markets, raw material working and dyeing (the only two production phases that are not externalized, being key activities) on the other side.

The case of Benetton highlights how SWOT analysis could be interpreted in a real case as a form of integration between competence theory and industrial organization respectively, though it could also be noted a sort of initial intuitous and a strong successive path dependency. The capabilities in logistics were born practically as a compelled choice, because of the small size of the firm at the beginning. Along the time, the Benetton family realized the potential of the other small firms in the Veneto region, for which Benetton's firm assumed the role of coordinator. At the same time, it was understood that globalization was arriving and for acting a primary role on international markets it was necessary a strong integration both upstream (distribution) and downstream (about raw materials).

It is interesting to note that today's many Benetton choices seem to be correct and rather expected, but it should be stressed its dynamic capabilities in anticipating the comprehension of competencies possessed and market requirements. For instance, after a long period during which many Benetton stores were in franchising, with many small shops all around the world, actually there were being created so-called "megastores" in crucial city locations directly controlled by Benetton.

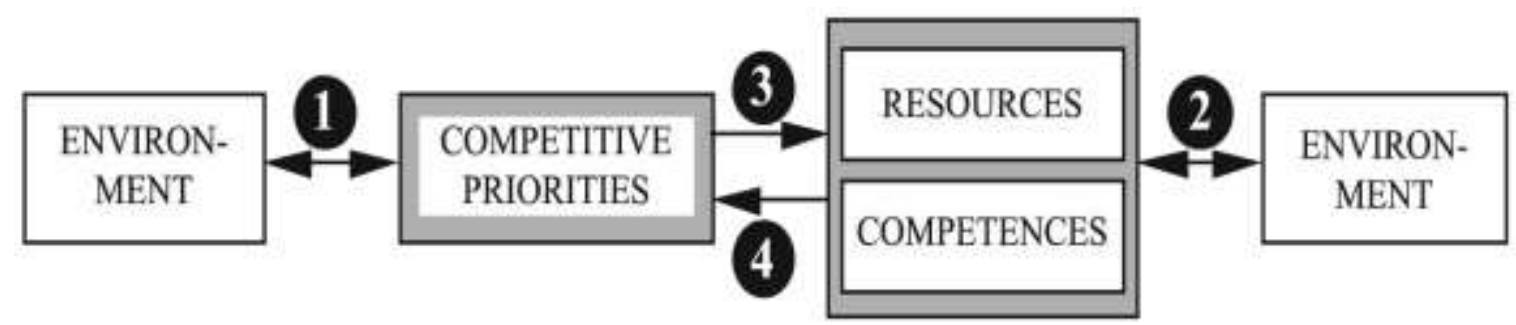

Figure 4. Consideration on the competitive priorities and the resources/competencies in the decision processes of management

\section{Conclusions}

The theme of competency is a rich and variegated area of study, dealing with aspects of firm policy, management of human resources, management of technology, innovation, etc. In this article competence theory has been carefully analyzed, not as an end in itself, but within the ambit of present-day ideas regarding strategic management.

We started by analyzing the limits of the dominant approach industrial organization which have often supplied the vital nourishment for the development and affirmation of competence theory. This theory, which in reality is a collection of principals can be traced back to various contributions generally summarized as resource-based view, competence-based competition and dynamic capabilities view (whose differences have been dealt with), enters the much broader context of the evolutionary theories, integrates organizational economics transactions costs' approach, and together with the behavioural decision theory makes up a theoretical block which more than one author has seen as the antithesis of orthodoxy.

The article was intended to be critical even in regard to the new approaches, stating their inadequacies, so as to provide a thorough understanding of entrepreneurial success. In short, the need to integrate new and old theories emerges. This is much greater than the apparent incompatibility, so industrial organization and competence theory must be considered together. Seeking the source of a firm's competitive advantage exclusively within the business in which it operates, or the resources it possesses, is limiting. 
Integration, in any case, is not simple, seeing that the logical paths revealing strategy in the two cases are different, not only in terms of sequence but also the elements considered. Industrial organization places emphases on the industry and the competitive environment (competition, suppliers, market, etc.) and considers strategy in the classical sense, that is, as performance objectives to be reached and levers to activate in order to obtain them. In contrast, in competence theory, the strategy is, above all, the exploitation the resources possessed and the acquisition of missing ones.

Some authors limit themselves to upholding the complementarity of the two theories. Porter (1980, 1985), for example, (who sees in them the solution to the "transversal" and "longitudinal" problems, that is, from an analysis of the competitiveness at a given instance in time) and Amit and Schoemaker (1993) (who use them to explain the origin of competitive success, found in the specific characteristics of the firm and in the industry to which it belongs).

Others (like Mahoney and Pandian (1992) or Foss and Eriksen (1995)) look for the unifying concepts, such as "isolation mechanisms" (interpreted as barriers to imitation at the level of the single firms, and as entrance barriers at the industry level) or "strategic propensities" (to imitate or differentiate itself from competitors by exploiting the fact of belonging to a certain industry, or distinguishing itself in regard to costs and times needed). Finally other authors highlight the firm's external world in order to select resources and support development of specific competencies by the firm.

The authors of this paper believe more in an integrated approach, understood as relations between elements of the two theories. The performance objectives to be followed, or one could say almost "imposed" and derived deterministically from outside, cannot leave out resources/competencies, whether possessed or lacking, from an analysis. Likewise the value analysis and management of the resources/competencies cannot be separated from the environment in which the firm operates or from the competitive priorities which the firm has set for itself.

The link between competitive priorities (performances at which to aim) and resources/ competencies is probably the key to settling the numerous discussions concerning competencies and their strategic value.

In conclusion, the new theme of firm's competence is not a different way of strategic planning, but rather an additional instrument to be used alongside the traditional analysis.

\section{References}

[1] Aaker, D.A. (1989), "Managing assets and skills: the key to a sustainable competitive advantage",California Management Review, Vol. 31, pp. 91-106.

[2] Amit, R. and Schoemaker, P.J.H. (1993), "Strategic intents and organizational rents", Strategic Management Journal, Vol. 14, pp. 33-46.

[3] Andrews, K.R. (1971), The Concept of Corporate Strategy, Dow Jones-Irwin, Homewwod, IL.

[4] Ansoff, I. (1965), Corporate Strategy, McGraw-Hill, New York, NY.

[5] Bain, J.S. (1968), Industrial Organization, John Wiley, New York, NY.

[6] Baker, J.C., Mapes, J., New, C. and Szwejczewski, M. (1997), "A hierarchical model of business competence", Integrated Manufacturing Systems, Vol. 8 No. 5, pp. 265-72.

[7] Barnett, W.P. and Burgelman, R.A. (1996), "Evolutionary perspectives on strategy", Strategic Management Journal, Vol. 17, pp. 5-19.

[8] Barney, J.B. (1991),"Firm resources and sustained competitive advantage”,Journal of Management, Vol.7 No. 1, pp. 99-120.

[9] Barney, J.B. (2001), "Is the resource-based view a useful perspective for strategic management research? Yes", Academy of Management Review, Vol. 26 No. 1, pp. 41-56.

[10] Chandler, A.D. (1962), Strategy and Structure: Chapters in the History of the Industrial Enterprise, MIT Press,Boston, MA.

[11] Cleveland, G., Schroeder, R.G. and Anderson, J.C. (1989), "A theory of production competence", Decision Sciences, Vol. 20 No. 4, pp. 655-8.

[12] Cockburn, I.M., Henderson, R.M. and Stern, S. (2000), "Untangling the origins of competitive advantage", Strategic Management Journal, Vol. 21, pp. 1123-45.

[13] Collis, D.J. and Montgomery, C.A. (1995), "Competing on resources: strategy in 1990s", Harvard Business Review, July/August, pp. 118-28. 
[14] Combs, J.G. and Ketchen, D.J. Jr (1999), "Explaining interfirm cooperation and performance: toward a reconciliation of predictions from the resource-based view and organizational economics",Strategic Management Journal, Vol. 20, pp. 867-88.

[15] Cyert, R. and March, J. (1963), A Behavioral Theory of the Firm, Prentice-Hall,Englewood ,Cliffs,NJ.

[16] D'Aveni, R.A. (1994), Hypercompetition: Managing the Dynamics of Strategic Maneuvering, TheFree Press, New York, NY.

[17] Dierickx, I. and Cool, K. (1989), "Asset stock accumulation and sustainability of competitive advantage", Management Science, Vol. 35 No. 12, pp. 1504-14.

[18] Dosi, G., Teece, D.J. and Winter, S. (1992), "Toward a theory of corporate coherence:preliminary remarks", in Dosi, G. (Ed.), Technology and Enterprise in a Historical Perspective,Clarendon Press, Oxford.

[19] Doz, Y. (1996), "Managing core competency for corporate renewal: towards a managerial theory of core competencies", in Dosi, G. and Malerba, F. (Eds), Organization and Strategy in the Evolution of Enterprise, Macmillan, London.

[20] Eisenhardt, K.M. and Martin, J.A. (2000), "Dynamic capabilities: what are they?", Strategic Management Journal, Vol. 21, pp. 1105-21.

[21] Eisenhardt, K.M.and Sull,D.N.(2001),“Strategy as simple rules”, Harvard Business Review,January, pp. 107-16.

[22] Foss, N.J. and Eriksen, B. (1995), "Competitive advantage and industry capabilities", in Montgomery, C.A. (Ed.), Resource-Based and Evolutionary Theories of the Firm, Kluwer,Boston, MA.

[23] Foss, N.J. and Mahnke, V. (2000), Competence, Governance, and Entrepreneurship: Advances in Economic Strategy Research, Oxford University Press, Oxford.

[24] Gerguri, S., Rexhepi, G., and Ramadani, V., (2013), Innovation strategies and competitive advantages, Modern Economics: Problems, Trends, Prospects, Vol.8, Issue 1, pp. 10-26 Ghemawat, P. (1991), Commitment: The Dynamic of Strategy, The Free Press, New York, NY. Grant, R.M. (1991), "The resource-based view of competitive advantage: implication for strategy formulation", California Management Journal, Vol. 33, Spring, pp. 114-34.

[25] Grant, R.M. (1996), "Toward a knowledge-based theory of the firm”, Strategic Management Journal,Vol.17,pp.109-22.

[26] Hall, R. (1993), "A framework linking intangible resources and capabilities to sustainable competitive advantage", Strategic Management Journal, Vol. 14, pp. 607-18.

[27] Hamel, G. and Prahalad, C.K. (1994), Competing for the Future, Harvard Business School Press, Boston, MA.

[28] Helfat, C.E. (2000), "Guest editor's introduction to the special issue: the evolution of firm capabilities", Strategic Management Journal, Vol. 21, pp. 955-9.

[29] Hisrich, R.D. and Ramadani, V. (2017), Effective Entrepreneurial Management, Springer, Cham.

[30] Hisrich, R.D. and Ramadani, V. (2017), Entrepreneurial Marketing, Edward Elgar, Cheltenham.

[31] Hitt, M.A., Ireland, R.D., Camp, S.M. and Sexton, D.L. (2001), "Guest editors' introduction to the special issue strategic entrepreneurship: entrepreneurial strategies for wealth creation", Strategic Management Journal, Vol. 22, pp. 479-91.

[32] Hofer, C.W.and Schendel,D.(1978),Strategy Formulation: Analytical Concepts, West Publishing Company,St Paul, MN

[33] Itami, H. and Numagami, T. (1992), "Dynamic interaction between strategy and technology", Strategic Management Journal, Vol. 13, pp. 119-35.

[34] Kim, J.S. and Arnold, P. (1992), "Manufacturing competence and business performance: a framework and empirical analysis", International Journal of Operations \& Production Management, Vol. 13 No. 10, pp. 4-25.

[35] King, A.W. and Zeithaml, C.P. (2001), "Competencies and firm performance: examining the causal ambiguity paradox", Strategic Management Journal, Vol. 22, pp. 75-99.

[36] Lee, C., Lee, K. and Pennings, J.M. (2001), "Internal capabilities, external networks, and performance: a study on technology-based ventures", Strategic Management Journal,Vol. 22, pp. 615-40. 
[37] Lei, D. and Slocum, J.W. Jr (1992), "Global strategy, competence-building and strategic alliances",California Management Review, Vol. 34, Fall, pp. 81-97.

[38] Lengnick-Hall, C.A. and Wolff, J.A. (1999), "Similarities and contradictions in the core logic of three strategy research streams", Strategic Management Journal, Vol. 20, pp. 1109-32.

[39] Lenz, R.T. (1980), "Strategic capability: a concept and framework for analysis", Academy of Management Review, Vol. 5 No. 2, pp. 225-34.

[40] Leonard-Barton, D. (1992), "Core capabilities and core rigidities: a paradox in managing new product development”, Strategic Management Journal, Vol. 13, pp. 111-25.

[41] Levinthal, D.A. (1995), "Strategic management and the exploration of diversity", in Montgomery, C.A. (Ed.), Resource-Based and Evolutionary Theories of the Firm, Kluwer, Boston, MA.

[42] Lippman, S. and Rumelt, R. (1982), "Uncertain imitability: an analysis of interfirm differences in efficiency under competition",The Bell Journal of Economics, Vol. 13 No.2,pp.418-38. Mahoney, J.T. and Pandian, J.R. (1992), "The resource-based view within the conversation of strategic management", Strategic Management Journal, Vol. 13, pp. 363-80.

[43] Makadok, R. (2001), "Toward a synthesis of the resource-based and dynamic-capability views of rent creation", Strategic Management Journal, Vol. 22, pp. 387-401.

[44] Meyer, M.H. and Utterback, J.M. (1993), "The product family and the dynamics of core capabilities", Sloan Management Review, Spring, pp. 29-47.

[45] Montgomery, C.A. (1995), "Of diamonds and rust: a new look at resources", in Montgomery,C.A.(Ed.),Resource-Based and Evolutionary Theories of the Firm, Kluwer, Boston, MA. Nelson,R.(1991),"Why do firms differ and how does it matter?"Strategic Management Journal,Vol.12,pp.61-74.

[46] Nelson,R.and Winter,S.(1982),An Evolutionary Theory of Economic Change,Harvard University Press, Cambridge, MA

[47] Penrose, E.T. (1959), The Theory of Growth of the Firm, Basil Blackwell, London.

[48] Porter, M.E. (1980), Competitive Strategy: Techniques for Analyzing Industries and Competitors, The Free Press, NY.

[49] Porter, M.E. (1985), Competitive Advantage: Creating and Substaining Superior Performance, The Free Press,NY.

[50] Porter, M.E. (1991), "Towards a dynamic theory of strategy",Strategic Management Journal, Vol.12,pp. 95-117.

[51] Porter,M.E.(1996),“What is strategy?”,Harvard Business Review, November/December,pp61-78.

[52] Prahalad, C.K. and Hamel, G. (1990), "The core competence of the corporation", Harvard BusinessReview, May/June, pp. 79-91.

[53] Prahalad, C.K. and Hamel, G. (1994), "Strategy as a field of study: why search for a new paradigm?",Strategic Management Journal, Vol. 15, pp. 5-16.

[54] Priem, R.L. and Butler, J.E. (2001), "Is the resource-based view a useful perspective for strategic management research?", Academy of Management Review, Vol.26 No.1,pp. 22-40.

[55] Ramadani, V., Gerguri, S., Rexhepi, G., and Abduli, S., (2013), Innovation and Economic Development - The Case of FYR of Macedonia, Journal of Balkan and Near Eastern Studies, Vol.15, No. 3, pp. 325-346

[56] Ramadani, V., and Gerguri, S., (2011), Innovations: Principles and Strategies, Strategic Change, Vol.20, Issue 3-4, pp. 101-110.

[57] Reed, R. and De Filippi, R. (1990), "Casual ambiguity, barriers to imitation and sustainable competitive advantage", Academy of Management Review, Vol. 15, pp. 88-102.

[58] Rouse, M.J. and Daellenbach, U.S. (1999), "Rethinking research methods for the resource-based perspective: isolating sources of sustainable competitive advantage", Strategic Management Journal, Vol. 20, pp. 487-94.

[59] Rugman, A.M. and Verbeke, A. (2002), "Edith Penrose's contribution to the resource-based view of strategic management", Strategic Management Journal, Vol. 23, pp. 769-80.

[60] Rumelt, R.P. (1991), “How much does industry matter?”,Strategic Management Journal, Vol. 12, pp. 167-85.

[61] Rumelt, R.P. (1995), "Inertia and transformation", in Montgomery, C.A. (Ed.), Resource-based and Evolutionary Theories of the Firm, Kluwer, Boston, MA. 
[62] Schoemaker,P.J.H. (1992), "How to link strategic vision to core capabilities",Sloan Management Review,Fall, pp.67-81.

[63] Schroeder, R.G., Bates, K.A. and Junttila, M.A. (2002), "A resource-based view of manufacturing strategy and the relationship to manufacturing performance", Strategic Management Journal, Vol. 23, pp. 105-17.

[64] Selznick, P. (1957), Leadership in Administration - A Sociological Interpretation, Harper \& Row, New York,

[65] Senge, P.M. (1990), “The leader's new work: building learning organizations”, Sloan Management Review, Summer, pp. 7-23.

[66] Snow, C.C. and Hrebiniak, L.G. (1980), "Strategy, distinctive competence and organizational performance", Administrative Science Quarterly, June.

[67] Spender, J.-C. (1996), "Making knowledge the basis of a dynamic theory of the firm", Strategic Management Journal, Vol. 17, pp. 45-62.

[68] Stacey, R.D. (1996), "The science of complexity: an alternative perspective for strategic change processes", Strategic Management Journal, Vol. 16, pp. 477-95.

[69] Stalk, G., Evans, P. and Shulman, L.E. (1992), "Competing on capabilities: the new rules of corporate strategy", Harvard Business Review, March/April, pp. 57-69.

[70] Teece, D.J., Pisano, G. and Shuen, A. (1997), "Dynamic capabilities and strategic management”,Strategic Management Journal, Vol. 18, pp. 509-33.

[71] Vickery,S.K (1991), “A theory of production competence revisited”, Decision Sciences, Vol.22 No.3,pp.635-643.

[72] Wernerfelt,B.(1984)“A resource-based view of the firm”Strategic Management Journ,Vol.5p171 Wernerfelt, B. (1995), "Resource-based strategy in a stochastic model”, in Montgomery, C.A. (Ed.), Resource-Based and Evolutionary Theories of the Firm, Kluwer, Boston, MA.

[73] Williamson,O.E.(1975),Markets and Hierarchies: Analysis and Antitrust Implications, The FreePress,New York

[74] Williamson, O.E. (1999), "Strategy research: governance and competence perspectives",Strategic Management Journal, Vol. 20, pp. 1087-108 